\title{
Mortality among firefighters from three northwestern United States cities
}

\author{
Paul A Demers, Nicholas J Heyer, Linda Rosenstock
}

\begin{abstract}
To explore whether exposure among firefighters to fire smoke could lead to an increased risk of cancer, lung disease, and heart disease, the mortality of 4546 firefighters who were employed by the cities of Seattle and Tacoma, WA and Portland, OR for at least one year between 1944 and 1979 were compared with United States national mortalities and with mortality of police officers from the same cities. Between 1945 and 1989, 1169 deaths occurred in the study population and 1162 death certificates $(99 \%)$ were collected. Mortality due to all causes, ischaemic heart disease, and most other non-malignant diseases was less than expected based upon United States rates for white men. There was no excess risk of overall mortality from cancer but excesses of brain tumours (standardised mortality ratio $($ SMR $)=2.09,95 \%$ confidence interval $(95 \%$ CI) 1.3-3-2) and lymphatic and haematopoetic cancers $(S M R=1.31,95 \% C I=0.9-1.8)$ were found. Younger firefighters ( $<40$ years of age) appeared to have an excess risk of cancer (SMR $=1.45,95 \%$ CI 0.8-2.39), primarily due to brain cancer (SMR $=3 \cdot 75,95 \%$ CI 1.2-8.7). The risk of lymphatic and haematopoetic cancers was greatest for men with at least 30 years of exposed employment $(S M R=2 \cdot 05$, $95 \%$ CI 1.1-3.6), especially for leukaemia (SMR $=2 \cdot 60,95 \%$ CI 1·0-5 4).
\end{abstract}

Since the end of the second world war the use of synthetic materials for both the structures and interiors of buildings has increased the complexity and toxicity of the smoke generated when these buildings catch fire. ${ }^{12}$ The potential exposure to suspected or known carcinogens has raised the

Department of Environmental Health

PA Demers, NJ Heyer, L Rosenstock

Department of Epidemiology

PA Demers

Department of Medicine, University of Washington, Seattle, Washington, USA

L Rosenstock concern that firefighters may be at excess risk of cancer. Benzene and polycyclic aromatic hydrocarbons are likely encountered at most fires and other, less common, exposures may include asbestos, aromatic amines, chlorinated dioxins, and other potential carcinogens. ${ }^{3-8}$ Excesses of brain cancer, cancers of the colon or rectum, malignant melanoma or skin cancer, bladder cancer, leukaemia, and multiple myeloma have been found, ${ }^{9-15}$ although the results have been far from consistent. Perhaps surprisingly, given a priori suspicions, only one cohort study has noted an excess of lung cancer in firefighters. ${ }^{16}$

It is plausible that firefighters could also be at excess risk of death due to heart and respiratory disease. Many respiratory irritants, such as hydrogen chloride, nitrogen dioxides, isocyanates, and acrolein, are commonly present in smoke. . $^{3-58}$ Evidence exists for respiratory dysfunction after acute high exposures ${ }^{17-19}$ although studies designed to look at chronic effects have produced mixed results. $^{20-23}$ An increased risk of cardiovascular disease due to intense physical and psychological stress after periods of inactivity or exposure to carbon monoxide and other toxic gases is also plausible. ${ }^{24-25}$ Most cohort mortality studies, however, have found firefighters to be at the same or lower risk than the general population for both heart and lung disease.

Death rates for the general population have been used as the reference in most mortality studies of occupational cohorts. A major bias introduced by using general population rates has been termed the healthy worker effect. ${ }^{26-28}$ In many ways firefighters, with their strict physical entry requirements and good employment benefits, typify a population in which a particularly strong healthy worker effect would be expected. This may in part account for the low risk of death due to heart and respiratory disease noted in these studies; however, when police, an occupation with similar entrance criteria, have been used as a reference population ${ }^{1429}$ evidence that firefighters are at increased risk of respiratory disease has been found. Also, a previously reported study of a sub-population of this same cohort found that the risk of heart disease increased with duration of employment. $^{30}$ 
In 1984 we began a retrospective cohort study of Seattle firefighters to explore the relation between exposure to fire smoke and mortality. ${ }^{30}$ Later we expanded the study to include two other major cities in the region and to collect data on police from the same cities as a comparison group. This is a report of the results of the expanded mortality study with follow up to the end of 1989.

\section{Methods}

The study population consists of all men who were employed as firefighters for at least one year between 1944 and 1979 by the cities of Seattle and Tacoma, Washington and Portland, Oregon. Women were excluded from the study because they first began employment as firefighters in the 1970 s and their numbers continue to be comparatively small. Years of active duty in positions involving fire combat was used as a surrogate measure of exposure to smoke. Records of the Seattle and Portland fire departments were reviewed and no time for exposure to fire smoke was assigned for years spent in administration, fire prevention, or support services. Because Tacoma lacked the necessary records to make this distinction, fire smoke exposure time was assigned for all years of firefighter employment. A cohort of police from the same cities was also identified for use as a comparison group.

The follow up period was from 1 January 1945 to 31 December 1989. Follow up for vital status and collection of death certificates were performed for both the firefighter and police cohorts using information from pension board and department records, the death records of Washington and Oregon, the records of the Washington and Oregon motor vehicle departments, and the National Death Index. Those who were lost to follow up were only considered at risk until the date on which they were last known to be alive. Persons lost to follow up subsequent to 1978 were assumed to be alive if no death was identified through the National Death Index. Underlying cause of death was coded by a former Washington state nosologist after information identifying the deceased person as either a former firefighter or police officer was removed from the death certificate.

Standardised mortality ratios (SMRs) compared with United States white men were calculated using the microcomputer version of the Occupational Mortality Analysis Program. ${ }^{31}$ Reference rates for United States white men were obtained from the National Institute for Occupational Safety and Health. White male rates were used because most firefighters from the cities studied were Caucasian and department records did not include information on race. Confidence intervals were calculated using a Poisson distribution. Incidence density ratios (IDRs) and $95 \%$ confidence intervals ( $95 \% \mathrm{CIs}$ ) for firefighters relative to police were calculated using Mantel-Haenszel methods with standardisation by five year age groups and time periods and test based confidence intervals. ${ }^{32}$ Mortality was examined in stratified analyses by years of fire combat exposure, years since first employment as a firefighter, and age at risk.

\section{Results}

Complete follow up was achieved for $98 \%$ of the 4401 firefighters (table 1). Between 1945 and 1989, 1169 deaths occurred and 1162 death certificates $(99 \%)$ were collected. The comparison cohort consisted of 3676 police officers and complete follow up information was attained for 3599 (98\%). During the follow up period 714 police deaths were identified and 703 death certificates $(98 \%)$ were collected.

The risk of death due to any cause among firefighters was less than expected (SMR $=0.81,95 \% \mathrm{CI}$ $0 \cdot 77-0.86$ ) due to a lower than expected risk of most types of non-malignant diseases (table 2). A twofold excess of brain tumours was seen $(S M R=2.09$, $95 \%$ CI $1 \cdot 31-3 \cdot 17)$. The death certificates listed seven of the tumours as glioblastoma multiforme, three as astrocytoma, three as other gliomas, five as other or unspecified malignant brain tumours, and four as unspecified brain tumours. Smaller excesses were found for cancers of the lymphatic and haematopoietic tissues (SMR $=1.31,95 \%$ CI $0.92-1.81$ ) and prostate $(S M R=1 \cdot 34,95 \%$ CI 0.90-1.91). The number of observed cases of most other cancers, including lung cancer, was similar to expected with only cancers of the bladder (SMR $=0.23,95 \% \mathrm{CI}$ $0.03-0.83)$ and kidney (SMR $=0.27,95 \%$ CI $0.03-0.97)$ significantly lower than expected. The

Table 1 Employment and vital status and years of follow up at 1 January 1990

\begin{tabular}{|c|c|c|c|c|c|}
\hline Status & Seattle & Portland & Tacoma & Total & $(\%)$ \\
\hline $\begin{array}{l}\text { Currently employed } \\
\text { Retired } \\
\text { Other alive } \\
\text { Deceased } \\
\text { Certificates collected } \\
\text { Unknown status } \\
\text { Total } \\
\text { Years of follow up }\end{array}$ & $\begin{array}{r}610 \\
782 \\
318 \\
516 \\
510 \\
55 \\
2281 \\
64388\end{array}$ & $\begin{array}{r}458 \\
396 \\
95 \\
509 \\
508 \\
24 \\
1482 \\
41085\end{array}$ & $\begin{array}{r}217 \\
239 \\
22 \\
144 \\
144 \\
16 \\
638 \\
17379\end{array}$ & $\begin{array}{r}1285 \\
1417 \\
435 \\
1169 \\
1162 \\
95 \\
4401 \\
122852\end{array}$ & $\begin{array}{c}(29) \\
(32) \\
(10) \\
(27) \\
(99)^{\star} \\
(2)\end{array}$ \\
\hline
\end{tabular}

^Per cent of death certificates collected. 
Table 2 Seattle, Portland, and Tacoma firefighter mortality: 1945-89

\begin{tabular}{|c|c|c|c|}
\hline Cause of death (ICD 9 codes) & Deaths & $S M R$ & $(95 \%)$ \\
\hline 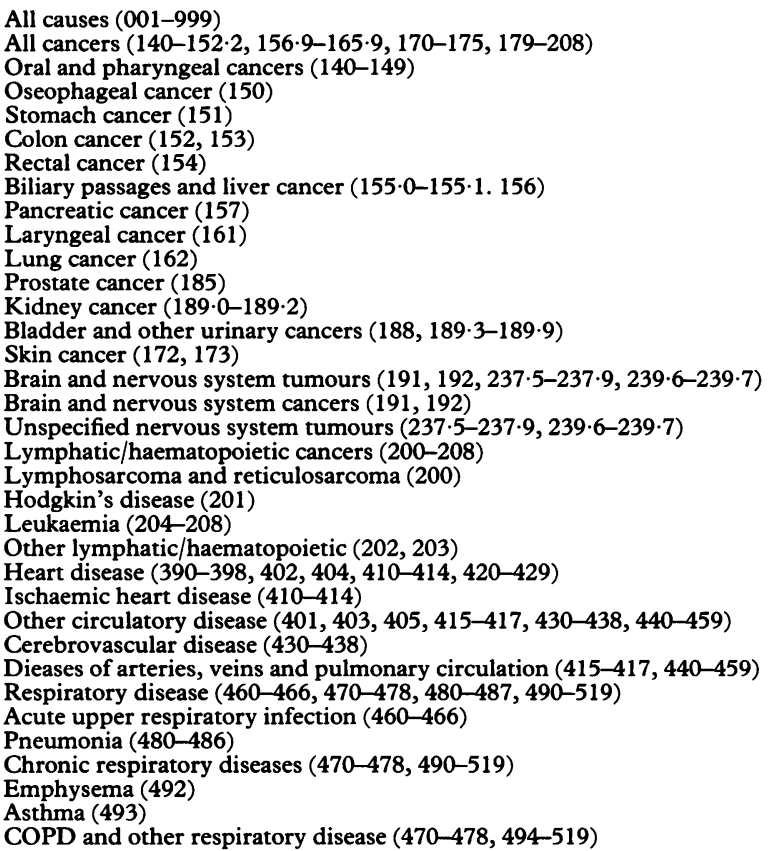 & $\begin{array}{r}1169 \\
291 \\
7 \\
6 \\
16 \\
24 \\
8 \\
6 \\
14 \\
2 \\
95 \\
30 \\
2 \\
2 \\
6 \\
22 \\
18 \\
4 \\
37 \\
7 \\
3 \\
15 \\
12 \\
461 \\
394 \\
131 \\
79 \\
48 \\
81 \\
2 \\
22 \\
56 \\
20 \\
3 \\
32\end{array}$ & $\begin{array}{l}0.81 \\
0.95 \\
0.81 \\
0.83 \\
1.07 \\
0.85 \\
0.95 \\
1.19 \\
0.89 \\
0.47 \\
0.96 \\
1.34 \\
0.27 \\
0.23 \\
0.98 \\
2.09 \\
2.07 \\
2.20 \\
1.31 \\
1.42 \\
1.05 \\
1.27 \\
1.40 \\
0.79 \\
0.82 \\
0.96 \\
0.85 \\
1.24 \\
0.89 \\
3.57 \\
0.67 \\
1.00 \\
1.19 \\
1.05 \\
0.98\end{array}$ & $\begin{array}{l}(0.77-0.86) \\
(0.85-1.07) \\
(0.33-1.66) \\
(0.30-1.80) \\
(0.61-1.73) \\
(0.54-1.26) \\
(0.41-1.87) \\
(0.44-2.59) \\
(0.49-1.49) \\
(0.06-1.70) \\
(0.77-1.17) \\
(0.90-1.91) \\
(0.03-0.97) \\
(0.03-0.83) \\
(0.36-2.13) \\
(1.31-3.17) \\
(1.23-3.28) \\
(0.60-5.62) \\
(0.92-1.81) \\
(0.57-2.93) \\
(0.22-3.08) \\
(0.71-2.09) \\
(0.72-2.44) \\
(0.72-0.87) \\
(0.74-0.90) \\
(0.80-1 \cdot 14) \\
(0.67-1.06) \\
(0.91-1.64) \\
(0.71-1.10) \\
(0.43-12.9) \\
(0.42-1.01) \\
(0.76-1.30) \\
(0.72-1.83) \\
(0.22-3.08) \\
(0.67-1.38)\end{array}$ \\
\hline
\end{tabular}

COPD $=$ Chronic obstructive pulmonary disease.

risks for death due to heart and circulatory disease were similar to or lower than expected with the exception of diseases of the arteries, veins, and pulmonary circulation, which were somewhat increased $(S M R=1 \cdot 24,95 \%$ CI 0.91-1.64).

Table 3 presents firefighter mortality relative to that of police and police mortality relative to that of United States white men for causes of death of a priori interest and those found to be in excess as shown in table 2. Hodgkin's disease, asthma, and acute respiratory infections were not included in the table because no deaths due to these causes were found among police. Although the confidence limits were wide, firefighters appear to have a higher risk than police of colon cancer, prostate cancer, brain tumours, "other" lymphatic and haematopoietic cancers, and emphysema. The category of "other" lymphatic and haematopoietic cancer includes multiple myeloma (seven out of 12 firefighter and two out of five police deaths were in this category). Although national rates for the study period were not available, the risk of multiple myeloma for firefighters relative to police was 1.91 (95\% CI $0.4-8 \cdot 4)$. Of the brain tumours among police, five were listed on the death certificates as glioblastoma multiforme, two as astrocytomas, and one as a malignant neuroblastoma.
Firefighters were at somewhat lower risk than police for deaths due to all causes and circulatory disease and at much lower risk of bladder cancer.

The causes of death that were found to be in excess were further analysed by duration of exposed employment (table 4). The risks for lymphatic and haematopoietic cancer, especially leukaemia, and diseases of the arteries, veins, and pulmonary circulation were highest for firefighters with at least 30 years of exposure, although the risks do not increase consistently with duration of exposed employment. The risk of leukaemia in firefighters with 30 years of exposed employment remained increased (IDR $=1 \cdot 80,95 \%$ CI 0.6-5.4) when comparisons were made with police, whereas the risk of all lymphatic and haematopoietic cancers did not (IDR $=1 \cdot 14,95 \%$ CI $0.5-2 \cdot 6)$. The risk of mortality from all chronic respiratory disease peaked among firefighters with 20 to 29 years of exposure; the excess risk of emphysema was highest among those with 10 to 19 years of exposure.

Lagging exposures by 10 years to allow for a latent period $^{33}$ increased the risk for 30 or more years of exposure for all lymphatic and haematopoietic neoplasms $\quad(S M R=2.73, \quad 95 \%$ CI $1.36-4 \cdot 88)$, leukaemia (SMR 3.63, 95\% CI 1.46-7.48), diseases 
Table 3 Seattle, Portland, and Tacoma firefighter mortality compared with police and police mortality compared with United States white male rates: $1945-89$

\begin{tabular}{|c|c|c|c|c|c|c|}
\hline \multirow[b]{2}{*}{ Cause of death } & \multicolumn{3}{|c|}{ Firefighters $v$ police } & \multicolumn{3}{|c|}{ Police v United States white men } \\
\hline & Deaths & $I D R$ & $(95 \% C I)$ & Deaths & $S M R$ & $(95 \% C I)$ \\
\hline All causes & 1169 & $0 \cdot 87$ & $(0.79-0.95)$ & 714 & 0.87 & $(0.81-0.93)$ \\
\hline All cancers & 291 & 0.97 & $(0 \cdot 80-1 \cdot 17)$ & 169 & 0.95 & $(0 \cdot 81-1 \cdot 11)$ \\
\hline Colon cancer & 24 & 1.58 & $(0.73-3.43)$ & 8 & 0.50 & $(0.22-0.99)$ \\
\hline Rectal cancer & 8 & 0.89 & $(0 \cdot 30-2 \cdot 66)$ & 5 & $1 \cdot 11$ & $(0.36-2 \cdot 59)$ \\
\hline Biliary passages and liver cancer & 6 & 0.71 & $(0 \cdot 19-2 \cdot 71)$ & 4 & 1.40 & $(0.38-3.59)$ \\
\hline Trachea, bronchus, and lung cancer & 95 & 0.95 & $(0 \cdot 67-1 \cdot 33)$ & 55 & 0.92 & $(0 \cdot 69-1 \cdot 19)$ \\
\hline Prostate cancer & 30 & 1.43 & $(0 \cdot 71-2 \cdot 85)$ & 11 & 1.02 & $(0.51-1 \cdot 82)$ \\
\hline Bladder cancer & 2 & $0 \cdot 16$ & $(0 \cdot 02-1 \cdot 24)$ & 4 & 0.91 & $(0 \cdot 25-2 \cdot 34)$ \\
\hline Skin cancer & 6 & $1 \cdot 12$ & $(0 \cdot 27-4 \cdot 76)$ & 4 & 0.94 & $(0 \cdot 26-2 \cdot 41)$ \\
\hline Brain and nervous system tumours & 22 & $1 \cdot 88$ & $(0 \cdot 82-4 \cdot 31)$ & 8 & $1 \cdot 14$ & $(0 \cdot 49-2 \cdot 25)$ \\
\hline Brain and nervous system cancer & 18 & 1.63 & $(0 \cdot 70-3 \cdot 79)$ & 8 & $1 \cdot 36$ & $(0.59-2.69)$ \\
\hline Lymphatic/haematopoietic cancers & 37 & $1 \cdot 03$ & $(0 \cdot 62-1 \cdot 73)$ & 21 & $1 \cdot 22$ & $(0 \cdot 75-1 \cdot 86)$ \\
\hline Lymphosarcoma and reticulosarcoma & 7 & 0.81 & $(0 \cdot 30-2 \cdot 22)$ & 5 & $1 \cdot 72$ & $(0.56-4.02)$ \\
\hline Leukaemia & 15 & $0 \cdot 80$ & $(0 \cdot 38-1 \cdot 70)$ & 11 & 1.56 & $(0 \cdot 78-2 \cdot 80)$ \\
\hline Other lymphatic/haematopoietic & 12 & $1 \cdot 40$ & $(0 \cdot 48-4 \cdot 07)$ & 5 & 0.93 & $(0 \cdot 30-2 \cdot 17)$ \\
\hline Other circulatory disease & 131 & 0.72 & $(0.54-0.96)$ & 86 & $1 \cdot 25$ & $(1.00-1.55)$ \\
\hline Cerebrovascular disease & 79 & 0.65 & $(0.45-0.92)$ & 59 & $1 \cdot 28$ & $(0.98-1.65)$ \\
\hline Diseases of the arteries, veins, and pulmonary circulation & 48 & 0.91 & $(0.54-1.52)$ & 25 & $1 \cdot 24$ & $(0 \cdot 70-2 \cdot 04)$ \\
\hline Respiratory disease & 81 & $1 \cdot 11$ & $(0 \cdot 71-1 \cdot 73)$ & 30 & 0.64 & $(0.43-0.91)$ \\
\hline Pneumonia & 22 & 1.04 & $(0 \cdot 46-2 \cdot 36)$ & 10 & 0.60 & $(0 \cdot 29-1 \cdot 11)$ \\
\hline Chronic respiratory diseases & 56 & $1 \cdot 11$ & $(0.65-1 \cdot 89)$ & 20 & 0.68 & $(0.42-1 \cdot 06)$ \\
\hline Emphysema & 20 & $1 \cdot 45$ & $(0.54-3.88)$ & 5 & 0.63 & $(0 \cdot 20-1 \cdot 46)$ \\
\hline COPD and miscellaneous lung disease & 32 & 0.89 & $(0.47-1.69)$ & 15 & 0.83 & $(0 \cdot 47-1 \cdot 37)$ \\
\hline
\end{tabular}

of the arteries, veins, and pulmonary circulation (SMR $=2 \cdot 55,95 \%$ CI 1.43-3.38), and colon cancer (SMR $=1 \cdot 69,95 \%$ CI $0 \cdot 77-3 \cdot 20)$. Lagging also further accentuated the risks for emphysema among firefighters with 20 to 29 years of exposed employment (SMR $=1 \cdot 49,95 \%$ CI 0.80-2.56).

Firefighters with at least 30 years since their first employment had increased risks for brain tumours (SMR = 2.63), lymphatic and haematopoietic malignancies $(S M R=1.48)$, prostate cancer $(S M R=1.42)$, diseases of the arteries, veins, and pulmonary circulation $(S M R=1.33)$, and emphysema (SMR = 1.39) (table 5). These firefighters also had an increased risk for brain tumours (IDR $=3 \cdot 62,95 \%$ CI $1 \cdot 2-11 \cdot 2$ ), prostate cancer (IDR $=1.58,95 \%$ CI $0.8-3 \cdot 2$ ), and emphysema (IDR $=1.48,95 \%$ CI $0.6-3.9)$ compared with police.

In general, the risk for mortality from most causes was highest among firefighters 65 years of age or older (table 6). Firefighters under the age of 40 , however, had an SMR for all cancers of 1.45 (95\% CI $0 \cdot 81-2 \cdot 39$ ) due primarily to a greater than expected number of brain tumours $(S M R=3.75)$ and lymphatic and haematopoietic malignancies (SMR = 1.74). The excess observed for cancer is by contrast with the deficits found for all non-cancer causes of death $(S M R=0 \cdot 47)$. The excess of cancer among firefighters under the age of 40 persisted when the comparison was made with police (IDR $=1.51$, $95 \%$ CI 0.7-3.5).

\section{Discussion}

We found an excess of brain tumours among firefighters compared with United States white men and police. Previous studies of workers exposed to vinyl chloride, acrylonitrile, and polycyclic aromatic hydrocarbons have noted excesses of brain cancer. ${ }^{34}$ Although it is difficult to quantify, it is likely that

Table 4 Seattle, Portland, and Tacoma firefighter mortality by duration of exposed employment: $1945-89$

\begin{tabular}{|c|c|c|c|c|c|c|c|c|c|c|c|c|}
\hline \multirow[b]{2}{*}{ Cause of death } & \multicolumn{3}{|c|}{$<10$ years } & \multicolumn{3}{|c|}{ 10-19 years } & \multicolumn{3}{|c|}{ 20-29 years } & \multicolumn{3}{|c|}{$\geqslant 30$ years } \\
\hline & Deaths & $S M R$ & $(95 \% C I)$ & Deaths & $S M R$ & $(95 \% C I)$ & Deaths & $S M R$ & $(95 \% C I)$ & Deaths & $S M R$ & $(95 \% C I)$ \\
\hline $\begin{array}{l}\text { Colon cancer } \\
\text { Prostate cancer } \\
\text { Brain and nervous system tumours } \\
\text { Lymphatic/haematopoietic cancers } \\
\text { Leukaemia } \\
\text { Diseases of the arteries, veins, and } \\
\text { pulmonary circulation }\end{array}$ & $\begin{array}{l}4 \\
3 \\
5 \\
4 \\
2 \\
4\end{array}$ & $\begin{array}{l}1.40 \\
2.42 \\
2.57 \\
0.91 \\
1.13 \\
1.36\end{array}$ & $\begin{array}{l}(0.4-3 \cdot 6) \\
(0.5-7 \cdot 1) \\
(0.8-6 \cdot 0) \\
(0 \cdot 2-2 \cdot 3) \\
(0 \cdot 1-4 \cdot 1) \\
(0.4-3 \cdot 5)\end{array}$ & $\begin{array}{l}2 \\
2 \\
8 \\
7 \\
2 \\
4\end{array}$ & $\begin{array}{l}0.54 \\
1.12 \\
3.53 \\
1.46 \\
1.04 \\
0.94\end{array}$ & $\begin{array}{l}(0 \cdot 1-2 \cdot 0) \\
(0 \cdot 1-4 \cdot 1) \\
(1 \cdot 5-7 \cdot 0) \\
(0 \cdot 06-3 \cdot 0) \\
(0 \cdot 1-3 \cdot 7) \\
(0 \cdot 3-2 \cdot 4)\end{array}$ & $\begin{array}{r}9 \\
14 \\
6 \\
14 \\
4 \\
15\end{array}$ & $\begin{array}{l}0.62 \\
1.23 \\
1.24 \\
1.06 \\
0.73 \\
0.79\end{array}$ & $\begin{array}{l}(0 \cdot 3-1 \cdot 2) \\
(0 \cdot 7-2 \cdot 1) \\
(0 \cdot 5-2 \cdot 7) \\
(0 \cdot 6-1 \cdot 8) \\
(0 \cdot 2-1 \cdot 9) \\
(0 \cdot 4-1 \cdot 3)\end{array}$ & $\begin{array}{r}9 \\
11 \\
3 \\
12 \\
7 \\
25\end{array}$ & $\begin{array}{l}1.21 \\
1.36 \\
2.04 \\
2.05 \\
2.60 \\
1.99\end{array}$ & $\begin{array}{l}(0 \cdot 6-2 \cdot 3) \\
(0 \cdot 7-2 \cdot 4) \\
(0 \cdot 4-5 \cdot 9) \\
(1 \cdot 1-3 \cdot 6) \\
(1 \cdot 0-5 \cdot 4) \\
(1 \cdot 3-2 \cdot 9)\end{array}$ \\
\hline $\begin{array}{l}\text { Chronic respiratory diseases } \\
\text { Emphysema }\end{array}$ & $\begin{array}{l}2 \\
1\end{array}$ & $\begin{array}{l}0.42 \\
0.92\end{array}$ & $\begin{array}{l}(0 \cdot 1-1 \cdot 5) \\
(0 \cdot 1-5 \cdot 1)\end{array}$ & $\begin{array}{l}5 \\
3\end{array}$ & $\begin{array}{l}0 \cdot 82 \\
1 \cdot 83\end{array}$ & $\begin{array}{l}(0 \cdot 3-1 \cdot 9) \\
(0 \cdot 4-5 \cdot 3)\end{array}$ & $\begin{array}{l}34 \\
12\end{array}$ & $\begin{array}{l}1 \cdot 15 \\
1 \cdot 35\end{array}$ & $\begin{array}{l}(0 \cdot 8-1 \cdot 6) \\
(0 \cdot 7-2 \cdot 4)\end{array}$ & $\begin{array}{r}15 \\
4\end{array}$ & $\begin{array}{l}0.97 \\
0.76\end{array}$ & $\begin{array}{l}(0 \cdot 5-1 \cdot 6) \\
(0 \cdot 2-1 \cdot 9)\end{array}$ \\
\hline
\end{tabular}


Table 5 Seattle, Portland, and Tacoma firefighter mortality by years since first employment: $1945-89$

\begin{tabular}{|c|c|c|c|c|c|c|c|c|c|}
\hline \multirow[b]{2}{*}{ Cause of death } & \multicolumn{3}{|c|}{$<20$ years } & \multicolumn{3}{|c|}{ 20-29 years } & \multicolumn{3}{|c|}{$\geqslant 30$ years } \\
\hline & Deaths & $S M R$ & $(95 \% C I)$ & Deaths & $S M R$ & $(95 \% C I)$ & Deaths & $S M R$ & (95\% CI) \\
\hline $\begin{array}{l}\text { Colon cancer } \\
\text { Prostate cancer } \\
\text { Brain and nervous system tumours } \\
\text { Lymphatic/haematopoietic cancers } \\
\text { Leukaemia } \\
\text { Diseases of the arteries, veins, and pulmonary } \\
\text { circulation }\end{array}$ & $\begin{array}{l}1 \\
0 \\
6 \\
8 \\
3 \\
1\end{array}$ & $\begin{array}{l}0.51 \\
0.00 \\
2.45 \\
1.65 \\
1.50 \\
0.51\end{array}$ & $\begin{array}{l}(0 \cdot 1-2 \cdot 9) \\
(0 \cdot 0-26 \cdot 6) \\
(0 \cdot 9-5 \cdot 3) \\
(0 \cdot 7-3 \cdot 2) \\
(0 \cdot 3-4 \cdot 4) \\
(0 \cdot 1-2 \cdot 8)\end{array}$ & $\begin{array}{l}3 \\
0 \\
2 \\
2 \\
1 \\
4\end{array}$ & $\begin{array}{l}0.66 \\
0 \cdot 00 \\
0.73 \\
0.39 \\
0.50 \\
0.91\end{array}$ & $\begin{array}{l}(0 \cdot 1-1 \cdot 9) \\
(0 \cdot 0-3 \cdot 1) \\
(0 \cdot 1-2 \cdot 6) \\
(0 \cdot 1-1 \cdot 4) \\
(0 \cdot 1-2 \cdot 8) \\
(0 \cdot 2-2 \cdot 3)\end{array}$ & $\begin{array}{l}20 \\
30 \\
14 \\
27 \\
11 \\
43\end{array}$ & $\begin{array}{l}0.91 \\
1.42 \\
2.63 \\
1.48 \\
1.40 \\
1.33\end{array}$ & $\begin{array}{l}(0 \cdot 6-1 \cdot 4) \\
(1 \cdot 0-2 \cdot 0) \\
(1 \cdot 4-4 \cdot 4) \\
(1 \cdot 0-2 \cdot 2) \\
(0 \cdot 7-2 \cdot 5) \\
(1 \cdot 0-1 \cdot 8)\end{array}$ \\
\hline $\begin{array}{l}\text { Chronic respiratory diseases } \\
\text { Emphysema }\end{array}$ & $\begin{array}{l}1 \\
0\end{array}$ & $\begin{array}{l}0.45 \\
0.00\end{array}$ & $\begin{array}{l}(0 \cdot 1-2 \cdot 5) \\
(0 \cdot 0-7 \cdot 9)\end{array}$ & $\begin{array}{l}2 \\
0\end{array}$ & $\begin{array}{l}0.32 \\
0.00\end{array}$ & $\begin{array}{l}(0 \cdot 1-1 \cdot 1) \\
(0 \cdot 0-1 \cdot 8)\end{array}$ & $\begin{array}{l}53 \\
20\end{array}$ & $\begin{array}{l}1 \cdot 12 \\
1 \cdot 39\end{array}$ & $\begin{array}{l}(0 \cdot 8-1 \cdot 5) \\
(0 \cdot 9-2 \cdot 2)\end{array}$ \\
\hline
\end{tabular}

exposure to polycyclic aromatic hydrocarbons at fires is common whereas exposure to vinyl chloride and acrylonitrile may happen onfy under certain conditions. If the excess of brain cancer were due to exposures that were not necessarily present at most fires, this might at least in part explain our finding that duration of exposed employment was not associated with increasing risk.

We also found an excess risk of leukaemia, which was highest among persons employed 30 or more years in fire combat positions, confirming our earlier finding of an increased risk among Seattle firefighters. ${ }^{30} \mathrm{~A}$ twofold excess of multiple myeloma relative to police was also found. Other studies have noted an excess of lymphatic and haematopoietic cancers of various histologies 1121415 and an excess of these malignancies is plausible given the exposure of firefighters to benzene. ${ }^{3-5}$ Although exposure to benzene is likely to be short term, measurements have been taken in excess of $100 \mathrm{ppm} .{ }^{34}$ Our ability to conclude with certainty an association with exposure to fire smoke is limited by our finding of a similar excess in police. We are unable to assess whether the excess among police is due to factors held in common between the two occupational groups, to some exposure unique to police, or to chance. Of interest, two other studies that have examined cancer in firefighters $v$ police found firefighters to be at higher risk for leukaemia. ${ }^{12} 14$

We also found an excess of prostate cancer, an effect of uncertain significance and not seen in other studies.
The persistence of this excess compared with police makes a diagnostic bias an unlikely explanation. We did not find excess cancers of the skin, bladder, or lung, which have been noted in some other studies of firefighters. Limited support was found for previously described excesses of colon cancer when the comparison was made with police, but not with the United States reference group. The inconsistency with previous studies may be due to the small number of deaths found for some sites or to the different methods used and varying time periods examined.

As anticipated, many of the results of this study are consistent with the healthy worker effect. One exception was deaths due to diseases of the arteries, veins, and pulmonary circulation, which were increased among firefighters with at least 30 years of exposed employment compared with both United States white men and police. This result is difficult to interpret given the heterogeneous nature of conditions in this category.

In analyses of this cohort performed with follow up through 1983 we found an excess of non-malignant respiratory disease compared with police (IDR = 1.59), as opposed to a deficit when compared with United States rates $(S M R=0 \cdot 88) .{ }^{29}$ One other study that compared deaths from lung disease in firefighters with those for police officers found a similar result. ${ }^{14}$ Although this disparity was also found in the current analysis, the magnitude of the effect was much reduced. This may be in part

Table 6 Seattle, Portland, and Tacoma firefighter mortality by age at risk: $1945-89$

\begin{tabular}{|c|c|c|c|c|c|c|c|c|c|}
\hline \multirow[b]{2}{*}{ Cause of death } & \multicolumn{3}{|c|}{ 18-39 years old } & \multicolumn{3}{|c|}{ 40-64 years old } & \multicolumn{3}{|c|}{$\geqslant 65$ years old } \\
\hline & Deaths & $S M R$ & $(95 \% C I)$ & Deaths & $S M R$ & $(95 \% C I)$ & Deaths & $S M R$ & $(95 \% C I)$ \\
\hline $\begin{array}{l}\text { Colon cancer } \\
\text { Prostate cancer } \\
\text { Brain and nervous system tumours } \\
\text { Lymphatic/haematopoietic cancers } \\
\text { Leukaemia } \\
\text { Diseases of the arteries, veins, and pulmonary } \\
\text { circulation }\end{array}$ & $\begin{array}{l}1 \\
0 \\
5 \\
5 \\
1 \\
1\end{array}$ & $\begin{array}{l}1 \cdot 38 \\
0.00 \\
3 \cdot 75 \\
1 \cdot 74 \\
0.82 \\
1 \cdot 21\end{array}$ & $\begin{array}{l}(0 \cdot 1-8 \cdot 2) \\
(0 \cdot 0-178) \\
(1 \cdot 2-8 \cdot 7) \\
(0 \cdot 6-4 \cdot 1) \\
(0 \cdot 1-4 \cdot 6) \\
(0 \cdot 1-6 \cdot 8)\end{array}$ & $\begin{array}{r}10 \\
4 \\
11 \\
13 \\
5 \\
7\end{array}$ & $\begin{array}{l}0.78 \\
0.86 \\
1.66 \\
0.96 \\
0.95 \\
0.56\end{array}$ & $\begin{array}{l}(0 \cdot 4-1 \cdot 4) \\
(0 \cdot 2-2 \cdot 2) \\
(0 \cdot 8-3 \cdot 0) \\
(0 \cdot 5-1 \cdot 6) \\
(0 \cdot 3-2 \cdot 2) \\
(0 \cdot 2-1 \cdot 1)\end{array}$ & $\begin{array}{r}13 \\
26 \\
6 \\
19 \\
9 \\
40\end{array}$ & $\begin{array}{l}0.86 \\
1.46 \\
2.34 \\
1.61 \\
1.67 \\
1.58\end{array}$ & $\begin{array}{l}(0 \cdot 5-1 \cdot 5) \\
(1 \cdot 0-2 \cdot 1) \\
(0 \cdot 9-5 \cdot 1) \\
(1 \cdot 0-2 \cdot 5) \\
(0 \cdot 8-3 \cdot 2) \\
(1 \cdot 1-2 \cdot 1)\end{array}$ \\
\hline $\begin{array}{l}\text { Chronic respiratory diseases } \\
\text { Emphysema }\end{array}$ & $\begin{array}{l}1 \\
0\end{array}$ & $\begin{array}{l}1 \cdot 11 \\
0.00\end{array}$ & $\begin{array}{l}(0 \cdot 1-6 \cdot 2) \\
(0 \cdot 0-37 \cdot 2)\end{array}$ & $\begin{array}{l}7 \\
3\end{array}$ & $\begin{array}{l}0.36 \\
0.50\end{array}$ & $\begin{array}{l}(0 \cdot 1-0 \cdot 7) \\
(0 \cdot 0-1 \cdot 5)\end{array}$ & $\begin{array}{l}48 \\
17\end{array}$ & $\begin{array}{l}1 \cdot 36 \\
1 \cdot 57\end{array}$ & $\begin{array}{l}(1 \cdot 0-1 \cdot 8) \\
(0 \cdot 9-2 \cdot 5)\end{array}$ \\
\hline
\end{tabular}


accounted for by the increasing availability and use of respiratory protection since the 1970 s. Also, the risk of death due to non-malignant respiratory disease among police was higher in the current $(S M R=0.64)$ than in the earlier analysis (SMR $=0.48$ ).

None the less, a raised risk of emphysema was found among firefighters compared with both United States white men and police. All of these deaths occurred among subjects at least 30 years after first employment and was highest among those with 10 to 29 years of exposed employment. If a relation does exist between exposure to fire smoke and emphysema, the fact that the risk was reduced among firefighters with 30 or more years of exposed employment might be due to those most susceptible to disease leaving employment early due to disability. Attempts to draw conclusions should be tempered by the fact that the specificity of death certificates is low for differentiating between different types of obstructive lung diseases. Whereas the results for all chronic respiratory diseases combined roughly parallel those for emphysema, the risks were of lesser magnitude.

Some limitations should be borne in mind when interpreting the results of this study. Firstly, duration of fire combat employment, although an improvement over total duration of employment, may still be an inadequate measure of exposure, particularly for substances that may not be present at all fires. Exposure may vary substantially between and within fires due to the composition of the material being burned, the temperature of the fire, and availability of oxygen. ${ }^{35}$ Thus the lack of association seen between duration or fire combat employment and various outcomes in this study may in part be due to the use of a poor surrogate for exposure.

Another limitation of this study is the lack of accuracy and specificity of information on cause of death on death certificates. In the case of heart and lung disease it may be difficult to assign a specific cause of death without a postmortem examination. Information about cancer on death certificates usually lacks detail and only rarely includes anatomical subsite or histological information. To the extent that a cause of death category contains a wide range of etiologically unrelated diseases, the relation between the exposure and any one specific disease will be obscured.

Police were chosen as an alternative reference population because they have a similar socioeconomic state, health benefits, and strict physical entry requirements, and are generally free from any major fire smoke inhalation. Two studies of smoking habits by occupation show that police and firefighters are similar, ${ }^{35}$ although a somewhat greater percentage of firefighters reported having never smoked. Because of the small number of police deaths, however, the risk estimates based upon them lack statistical stability and their confidence limits are correspondingly wide. Also, police have rarely been studied and their occupational exposures and risks for death due to various causes have not been well characterised. An excess or deficit of deaths among police could be due to their own unique exposures or characteristics and thus lead to spurious conclusions about firefighters. Potential police exposures include psychological stress and motor vehicle exhausts. The magnitude and health effects of these exposures are not fully known and their potential for introducing bias should be borne in mind.

In conclusion, this study found excesses of brain cancer and leukaemia among city firefighters from the northwest United States and suggests that they may be at excess risk of dying from emphysema. Exposures to known carcinogens and respiratory irritants are likely to explain these findings; future efforts should be directed towards reducing and eliminating these exposures.

This research was funded through a cooperative agreement with the United States Fire Administration of the Federal Emergency Management Agency (EMW 85-K-2089). Paul Demers is supported by a training grant in environmental epidemiology and biostatistics from the National Institute for Environmental Health Sciences (T32 ES07262). We thank the Fire and Police Pension Boards, Departments and Unions of Seattle and Tacoma, Washington and Portland, Oregon, and Rebecca Hubbard.

Requests for reprints to: Linda Rosenstock MD, Occupational Medicine Programme, ZA-66, University of Washington, 325 9th Avenue, Seattle, WA 98104.

1 National Research Council. Fire and smoke: understanding the hazards. Washington DC: National Academy Press, 1986.

2 Birky MM, Clarke FB. Inhalation of toxic products from fires. Bull N Y Acad Med 1981;57:997-1013.

3 Brandt-Rauf PW, Fallon LF, Tarantini T, Idema C, Andrews L. Health hazards of fire fighters: exposure assessment. $\mathrm{Br}$ J Ind Med 1988;45:606-12.

4 Treitman RD, Burgess WA, Gold A. Air contaminants encountered by firefighters. Am Ind Hyg Assoc J 1980;41: 796-802.

5 Lowry WT, Juarez L, Petty CS, et al. Studies of toxic gas production during actual structural fires in the Dallas area. J Forensic Sci 1985;30:59-72.

6 Bumb RR, Crummett WB, Cutie SS, et al. Trace chemistries of fire: a source of chlorinated dioxins. Science 1980;210:385-90.

7 Hartzell GE, Packham SC, Switzer WG. Toxic products from fires. Am Indust Hyg Assoc J 1983;44:248-55.

8 Gold A, Burgess WA, Clougherty EV. Exposure of firefighters to toxic air contaminants. Am Ind Hyg Assoc J 1978;39:534-9.

9 Vena JE, Fiedler RC. Mortality in a municipal workers cohort: IV. fire fighters. Am J Ind Med 1987;11:671-84.

10 Eliopulos E, Armstrong BK, Spickett JT, Heyworth F Mortality of fire fighters in Western Australia. $\mathrm{Br} J$ Ind Med 1984;41:183-7.

11 Office of Population Censuses and Surveys. Occupational mortality, the Registrar General's decennial supplement for Great Britain, 1979-80, 1982-83. London: HMSO, 1986.

12 Sama SR, Martin TR, Davis LK, Kriebel D. Cancer incidence among Massachusetts firefighters, 1982-1986. Am J Ind Med 1990;18:47-54. 
13 Beaumont JJ, Chu GST, Jones JR, et al. An epidemiologic study of mortality from cancer and other causes in San Francisco firefighters. Am J Ind Med 1991;19:357-72.

14 Feuer E, Rosenman K. Mortality in police and firefighters in New Jersey. Am J Ind Med 1986;9:517-27.

15 Howe GR, Burch JD. Fire fighters and risk of cancer: an assessment and overview of the epidemiologic evidence. Am J Epidemiol 1990;132:1039-50.

16 Hansen ES. A cohort study on the mortality of firefighters. $\mathrm{Br} \mathrm{J}$ Ind Med 1990;47:805-9.

17 Kirkpatrick M, Bass J. Severe obstructive lung disease after smoke inhalation. Chest 1979;76:108-10.

18 Loke J, Farmer W, Matthay R, Putman C, Smith G. Acute and chronic effects of firefighting on pulmonary function. Chest 1980;77:369-73.

19 Whitener DR, Whitener LM, Robertson KJ, et al. Pulmonary function measurements of patients with thermal injuries and smoke inhalation. Am Rev Respir Dis 1980;122:731-9.

20 Peters JM, Theriault GP, Fine LJ, Wegman DH. Chronic effects of firefighting on pulmonary function. $N \mathrm{Engl} J \mathrm{Med}$ 1974;291:1320-2.

21 Unger K, Snow R, Mestas J, Mille W. Smoke inhalation in firemen. Thorax 1980;35:838-42.

22 Sparrow D, Bosse R, Rosner B, Weils S. The effects of occupational exposure on pulmonary function-a longitudinal evaluation of firefighters and non-firefighters. Am Rev Respir Dis 1982;123:319-22.

23 Musk AW, Peters JM, Berstein L, Rubin C, Monroe CB. Pulmonary function in firefighters III: a six year follow-up in the Boston Fire Department. Am J Ind Med 1982;3:369-73.

24 Radford EP, Levine MS. Occupational exposure to carbon monoxide in Baltimore firefighters. J Occup Med 1976;18: 628-34.

25 Goldsmith JR, Aronow WS. Carbon monoxide and coronary heart disease: A review. Environ Res 1975;10:236-48.

26 Monson RR. Observations on the healthy worker effect. J Occup Med 1986;28:425-33.

27 Fox AJ, Collier PF. Low mortality rates in industrial cohort studies due to selection for work and survival in the industry. British Journal of Preventive and Social Medicine 1976;30: 225-30.

28 Gilbert ES. Some confounding factors in the study of mortality and occupational exposures. Am J Epidemiol 1982;116: 177-88.

29 Rosenstock L, Demers P, Heyer NJ, Barnhart S. Respiratory mortality among firefighters. Br J Ind Med 1990;47:462-5.

30 Heyer N, Weiss N, Demers P, Breslow N, Rosenstock L. Cohort mortality study of Seattle firefighters: $1945-1983$. Am J Ind Med 1990;17:493-504.

31 Marsh GM, Preininger M. OCMAP: a user-oriented occupational mortality analysis program. American Statistician 1980;34:245.

32 Kleinbaum DG, Kupper LL, Morgenstern H. Epidemiologic research: principles and quantitative methods. New York: Von Nostrand Reinhold, 1982.

33 Checkoway H, Pearce N, Hickey JL, Dement JM. Latency analysis in occupational epidemiology. Arch Environ Health 1990;45:95-100

34 Thomas TL, Waxweiler RJ. Brain tumors and occupational risk factors: a review. $S$ cand J Work Environ Health 1986;12:1-15.

35 Brackbill B, Frazier T, Shilling S. Smoking characteristics of US workers 1978-80. Am J Ind Med 1988;13:5-42.

36 Stellman SD, Boffetta P, Garfinkel L. Smoking habits of 800,000 American men in relation to their occupation. Am J Ind Med 1988;13:43-58.

Accepted 2 December 1991. 